\title{
Determination of Ghost Fishing Starting Time by Four Different Baited Fish Traps in the Çanakkale Strait (North Aegean Sea)
}

\author{
Talip İbin ${ }^{1}$, Adnan Ayaz $^{2 *}$ \\ ${ }^{1}$ Yalova University, Altınova Vocational School, Yalova, Turkey, \\ ${ }^{2 *}$ Çanakkale Onsekiz Mart University, Marine Science and Technology Faculty, Fisheries Department, 17100, Çanakkale, Turkey \\ Correspondent: adnanayaz@comu.edu.tr \\ Received: 29.04.2021 Accepted: 11.06.2021 \\ Talip İbin: Orcid 0000-0002-5378-2574 \\ Adnan Ayaz: Orcid 0000-0003-4839-9244
}

How to cite this article: İbin, T. \& Ayaz, A., (2021). Determination of ghost fishing starting time by four different baited fish traps in the Çanakkale Strait (North Aegean Sea). COMU J. Mar. Sci. Fish, 4(1): 42-52. DOI: 10.46384/jmsf.929737

\begin{abstract}
In this study, the starting time of ghost fishing in baited fish traps were determined. Two separate trials using 4 different types of fish traps (foldable, conical, "O" shaped Round and cylindrical) were carried out in the Çanakkale Strait at a depth of $5 \mathrm{~m}$ between July - December 2013. A total of 12 fish traps (3 for each trap type) were used in the study. Each trial lasted a period of 45 days. Major features of the traps were as follows: the foldable fish trap had "V" shaped inclined funnel; the conical fish trap had a conical entrance from the top; The "O" shaped fish trap had a "V" shaped entrance on the base; the cylindrical trap had a conical entrance on the side. In all trials fresh sardine, black mussel and bread placed in a net bag were used as bait and fixed in the traps. Underwater observations showed that fish entrapped in all trap types escaped from the traps within 8-10 days. Fish mortality was due to accidental entanglement of fish on the mesh material covering the traps or due to predation. Molluscs such as octopuses and squids escaped within 4-7 days whereas crabs suffered from cannibalism or starvation due to their lower escape rates. In conclusion, in the present study while trap ghost fishing for fish and cephalopods were not observed, ghost fishing for crabs were observed and was a factor of entrance design and location on traps.
\end{abstract}

Keywords: Ghost Fishing, Fish Trap, Çanakkale Strait

\section{Çanakkale Boğazı'nda (Kuzey Ege Denizi) Yemli Balık Tuzaklarının Hayalet Avcılığa Başlama Süresinin Belirlenmesi}

Özet: Bu çalışmada, yemli balık tuzaklarında hayalet avcılığına başlama zamanının belirlenmesi amaçlanmıştır. Bu amaçla, Çanakkale Boğazı'nda katlanabilir ve tabandan bağımsız "V" şekilli, üstten konik girişli konik sepet, "O" şekilli sepete tabandan "V" şekilli ve silindirik sepete yandan konik girişli olmak üzere 4 farklı tuzak, $5 \mathrm{~m}$ su derinliğinde, Temmuz - Aralık 2013 tarihleri arasında iki farklı deneme gerçekleştirilmiştir. Çalışmada her bir sepet modelinde 3 adet olmak üzere toplamda 12 adet sepet kullanılmıştır. Her bir deneme 45 gün sürmüştür. Denemelerde yem olarak, sardalye eti, kara midye ve ekmek kullanılmış ve bu yemler ağdan yapılmış bir filenin içine konularak sepetlerin içine sabitlenmiştir. Denemeler sonucunda tuzağa düşen balıkların 8-10 gün içinde tuzaktan kaçtığı sonucuna varıldı. Sepetlerde meydana gelen balık ölümleri tuzakların kaplama malzemelerine dolanmalarından ya da predatör saldırıları sonucu meydana geldiği gözlenmiştir. Kafadanbacaklılardan ahtapot ve mürekkep balıklarının 4-7 gün arasında kaçtığı, yengeç gibi kabukluların kaçmayı başaramadığı ve kanibalizmden veya açlıktan öldükleri tespit edilmiştir. Sonuç olarak, denemelerde kullanılan tuzakların balıklar ve kafadanbacaklılar üzerinde hayalet avcılık etkisi olmadığ 1 belirlenmiş, yengeçlerde ise giriş tipine göre ciddi bir hayalet avcılık etkisi olduğu belirlenmiştir.

Anahtar Kelimeler: Hayalet Avcılık, Balık Tuzağı, Çanakkale Boğazı 


\section{Introduction}

Ghost fishing is defined as continuation of fishing by broken, lost or abandoned fishing gears in aquatic environments (Smolowitz, 1978a, b; Ayaz, 2003; Ayaz et al., 2004; Ayaz et al., 2006a, b; Ayaz et al., 2010). When fishing with traps, the captured animals remain alive and therefore, unwanted or by-catch species can be returned to their natural environment (ICES, 2007). However, fish traps, which are important fishing gears in terms of sustainable fishing, can lead to some undesirable effects such as ghost fishing.

In determining the extent of the problem, studies have been conducted to find out the amount of lost fish traps and how long the lost fish traps can continue ghost fishing. It has been reported that the effect of some fish traps can last for 7- 15 years and even for 30 years (Breen, 1987; Parrish \& Kazama, 1992; Guillory, 1993; Stevens et al., 2000; Bullimore et al., 2001; Hebert et al., 2001; Al-Masroori et al., 2004; Campbell \& Sumpton, 2009).

However, experimental studies designed to determine the duration of ghost fishing are limited (Breen, 1985; Bullimore et al., 2001; Hebert et al., 2001; Al-Masroori et al., 2004; Ayaz et al., 2006a, b).

Studies on prevention of ghost fishing have focused on placing fusible escape mechanisms to baited fish traps or escape windows that allow individuals under the legal dimension to escape, and construction of the escape intervals for fish (Nulk, 1978; Pecci et al., 1978; Scarsbrooke et al., 1988; Guillory, 1989; Guillory \& Hein, 1998; Guillory \& Prejean, 1998; Shepherd et al., 2002).

There are only a few studies designed to prevent ghost fishing in baited fish traps, by destroying the traps after a certain period of time in the marine environment (Kim et al., 2014a, b). It is very difficult for fishermen to adopt this approach, as no fisherman wants to damage their traps spontaneously after using a certain amount of time. Instead of this approach, it would be a more correct approach if a part of the trap is opened after a certain time in the sea, and its fishing capacity is ended. In order to carry out these studies, it is necessary to know when these parts of the traps should be opened after being lost at sea. This period to be determined is the time until the species that enter a lost trap begin to die from starvation or cannibalism. This time can be called the time of traps to start ghost fishing. In this study, it is aimed to determine the ghost fishing starting time of different fish traps types.

\section{Material and Methods}

The study was carried out in predetermined near shore stations off Dardanos Campus, Çanakkale Onsekiz Mart University between July - December 2013. The area was naturally sheltered and monitored daily to prevent unauthorized access. (Figure 1).

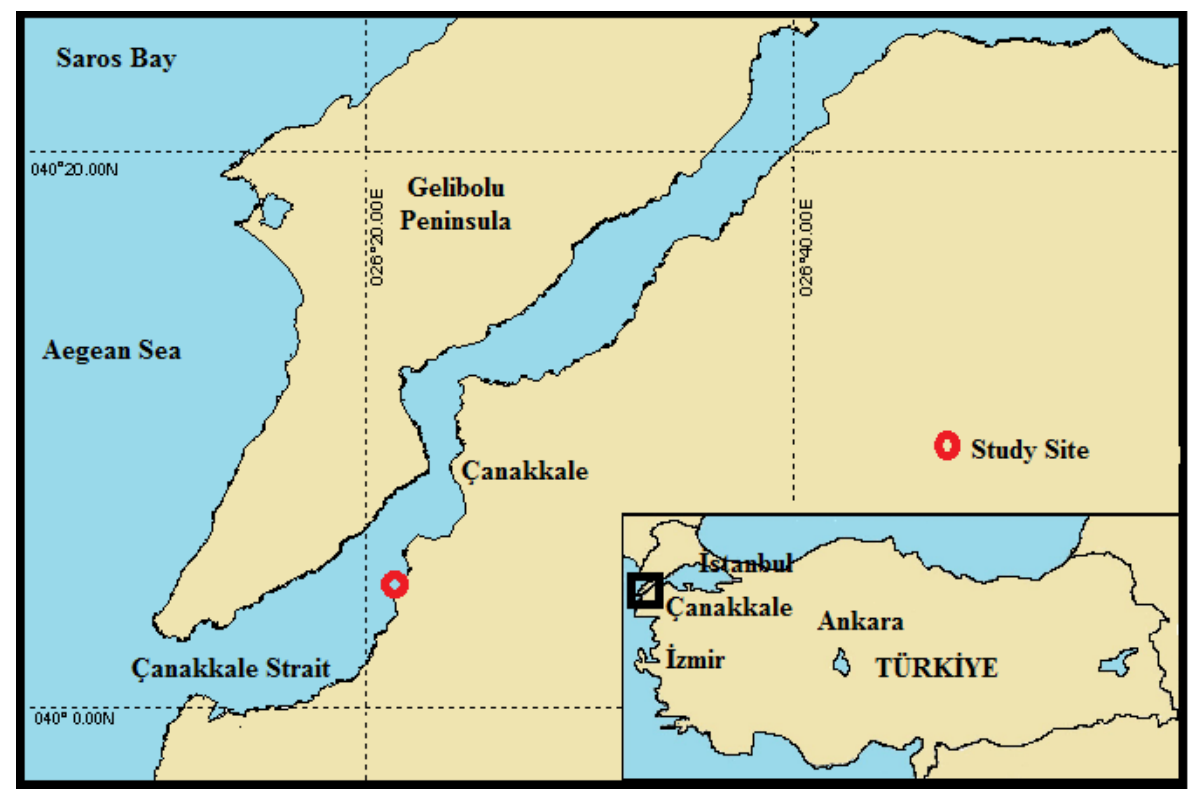

Figure 1. Study Area.

In all trials, 4 types of fish traps were used: foldable, conical, "O" shaped (Round) and cylindrical (Figure 2 and 3). Only the conical trap had entrance from the top, while others had entrances from the side. (Figure 2 and 3 ). A total of 12 traps ( 3 for each type), were used. All traps had equal volumes with a mean of $0.162 \pm 0.001 \mathrm{~m}^{3}$. All traps were made of steel profiles covered with a mesh material having a rope thickness of $210 \mathrm{~d} / 18$ and mesh width of 18 $\mathrm{mm}$. 


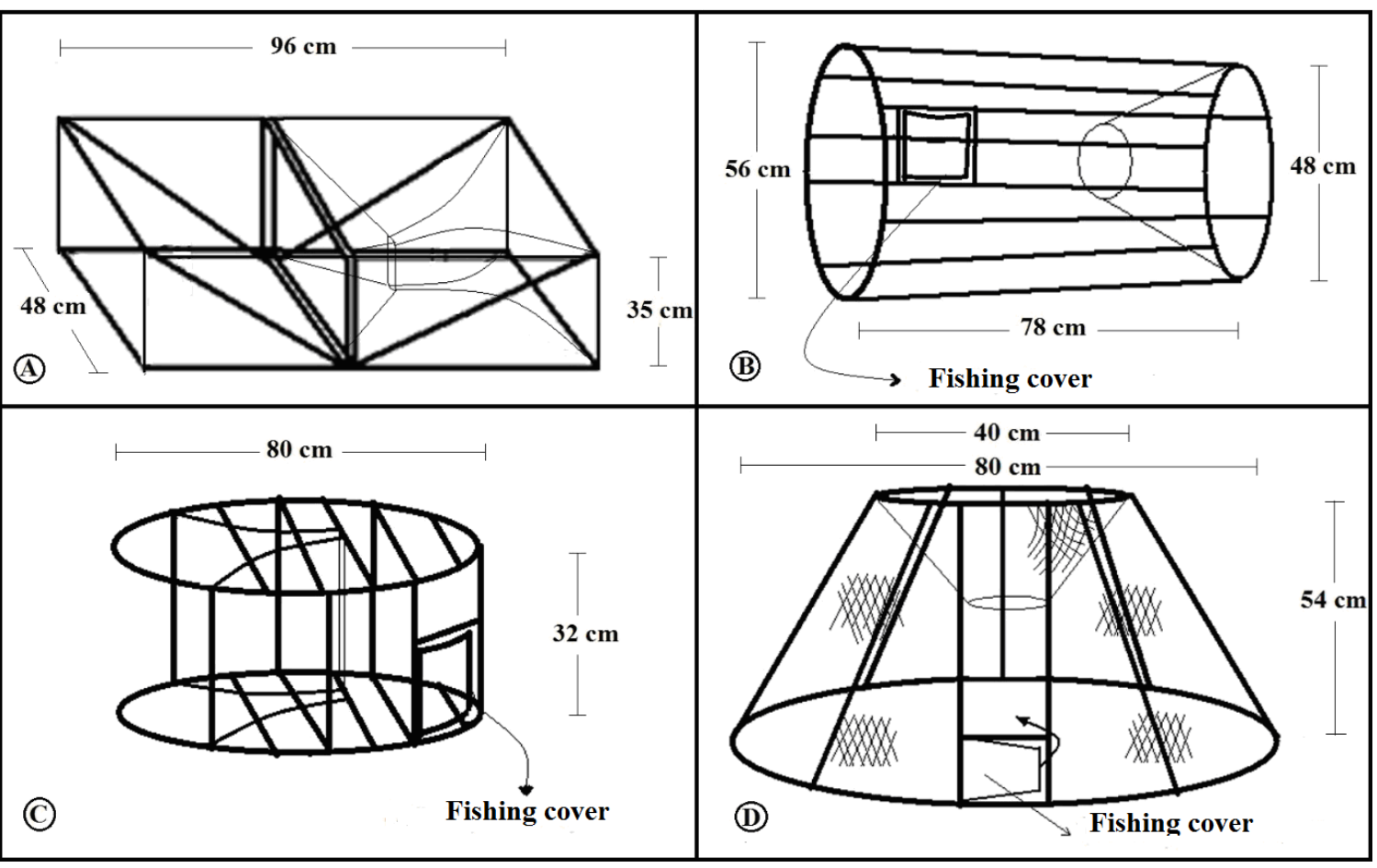

Figure 2. Plans of fish trap models used in trials (A: Foldable; B: Cylindrical; C: O "shaped; D: Conical fish trap).

Two different trials that lasted 45 days each were made to determine the starting time of fish traps for ghost fishing. The first trial was conducted between 27 July - 9 September 2013 and the second trial was conducted between 12 September - 22 November 2013. In the first trial, sea water temperature increased from $23{ }^{\circ} \mathrm{C}$ to $24{ }^{\circ} \mathrm{C}$ and in the second decreased from $22{ }^{\circ} \mathrm{C}$ to $16^{\circ} \mathrm{C}$.

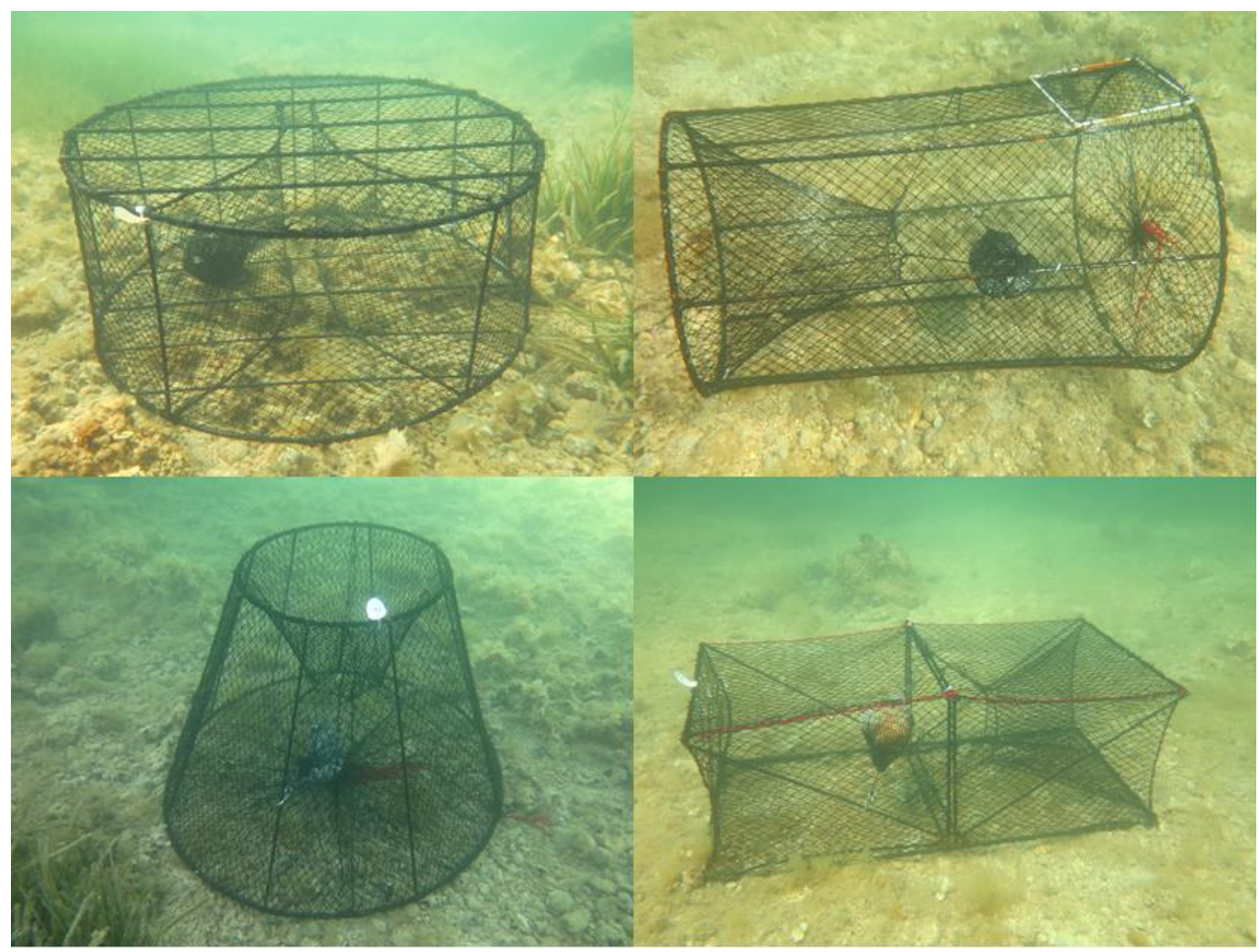

Figure 3. Underwater images of fish traps used in trials. 
In the experiments, fresh European sardine (Sardina pilchardus), black mussels (Mytilus galloprovincialis) and bread were used as bait. Baits were placed in a net bag and fixed inside the traps. Baits were placed separately in each trap. Traps were placed on seafloor by divers at a depth of $5 \mathrm{~m}$. The number of fish in each trap was determined daily until the trial was terminated. Independent observations by two different divers allowed comparison of the number of fish in traps. In case of discrepancy, number of fish in traps were recounted.
In addition to total number of fish in traps, the entry and escape status of each species was carefully recorded. The trials were terminated when first mortality was observed.

\section{Results}

In the experiments, 14 fish species belonging to 7 families, 2 cephalopods and 1 crustacean belonging to 2 families were recorded inside fish traps. Results are given in Table 1. Overall, Sparidae family was represented by highest number of species.

Table 1. List of species recorded in fish traps

\begin{tabular}{|c|c|c|}
\hline Family & Species & Trap Type \\
\hline \multirow{2}{*}{ Labridae } & Symphodus tinca & "O" shaped \\
\hline & Symphodus rostratus & "O" \& Foldable \\
\hline \multirow{2}{*}{ Serranidae } & Serranus cabrilla & All Models \\
\hline & Serranus scriba & All Models \\
\hline \multirow{6}{*}{ Sparidae } & Spondyliosoma cantharus & "O" shaped \\
\hline & Diplodus annularis & All Models \\
\hline & Diplodus vulgaris & "O" shaped, Foldable \& Conical \\
\hline & Diplodus sargus & "O" shaped \\
\hline & Sarpa salpa & "O" shaped \\
\hline & Diplodus puntazzo & All Models \\
\hline Gobiidae & Gobius sp. & Foldable \\
\hline Scorpaenidae & Scorpaena porcus & "O" shaped, Foldable \& Cylindrical \\
\hline Congridae & Conger conger & "O" shaped, Foldable \& Conical \\
\hline Mullidae & Mullus surmuletus & "O" shaped \& Foldable \\
\hline Octopodidae & Octopus vulgaris & Foldable, Cylindrical \& Conical \\
\hline Sepiidae & Sepia officinalis & "O" shaped \\
\hline Majidae & Maja crispata & All Models \\
\hline
\end{tabular}

Changes in total catch values over time are are given in Figures 4 and 5. Fish data, include all species caught in traps whereas crab data include a single species, Maja crispata. Cephalopods such as octopus and cuttlefish were not included in data analysis due to their small numbers in traps and their ability to exit from the fish traps by the end of the day.

Our underwater observations indicated that attractiveness of baits decreased in traps after 7 days and were completely lost after 15 days. Daily fluctuations in total fish number suggested that fish could easily swim out of fish traps.
In the present study, "O" shaped traps caught the highest number of fish. This trap type had a groundlevel "V" entrance. Daily catch rates of "O" shaped traps are given in Figures 6 and 7 for the first and second trials, respectively. Daily fluctuations in total fish number suggested that fish could easily swim in and out of fish traps. Throughout the trials, only a single crab was observed inside the "O" shaped trap which moved in and out of the traps easily. In both trials, cannibalism and ghost fishing were not observed. 


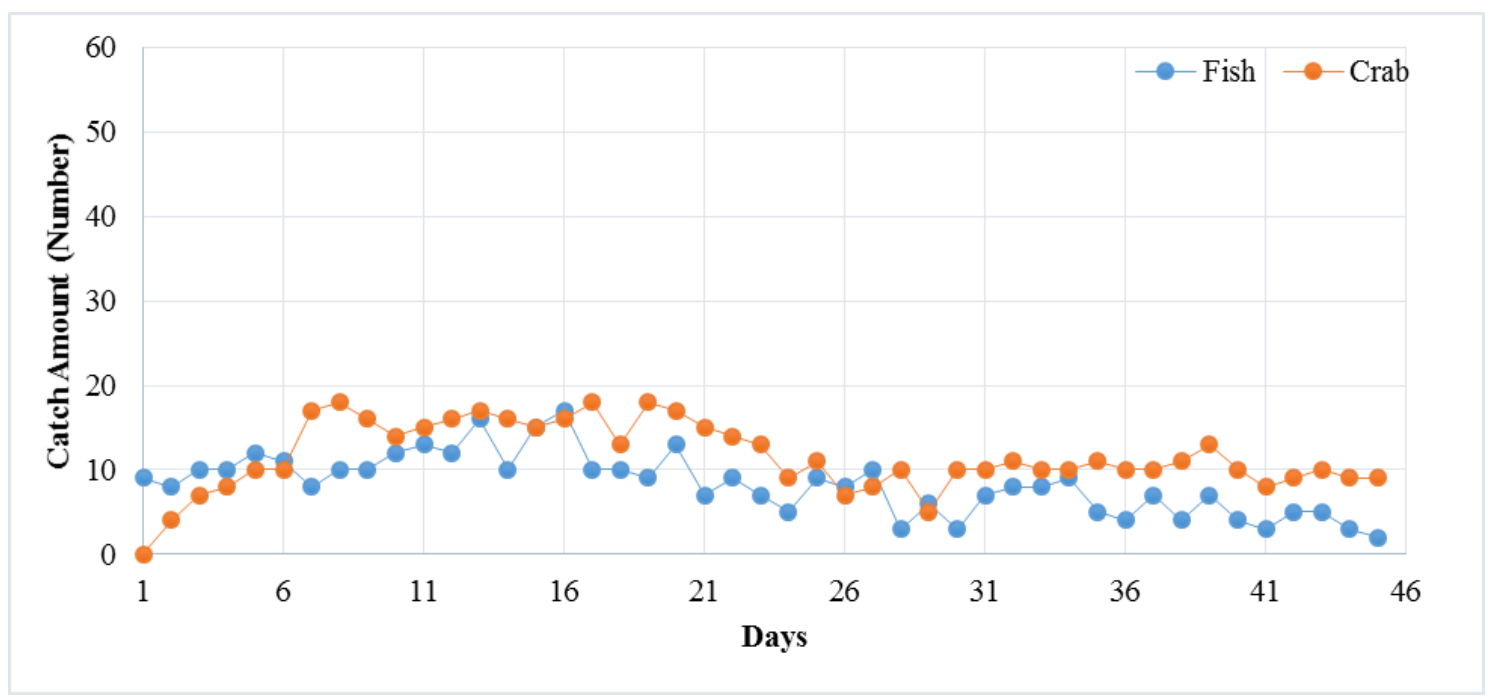

Figure 4. Change in total catch values in fish traps over time in trial 1.

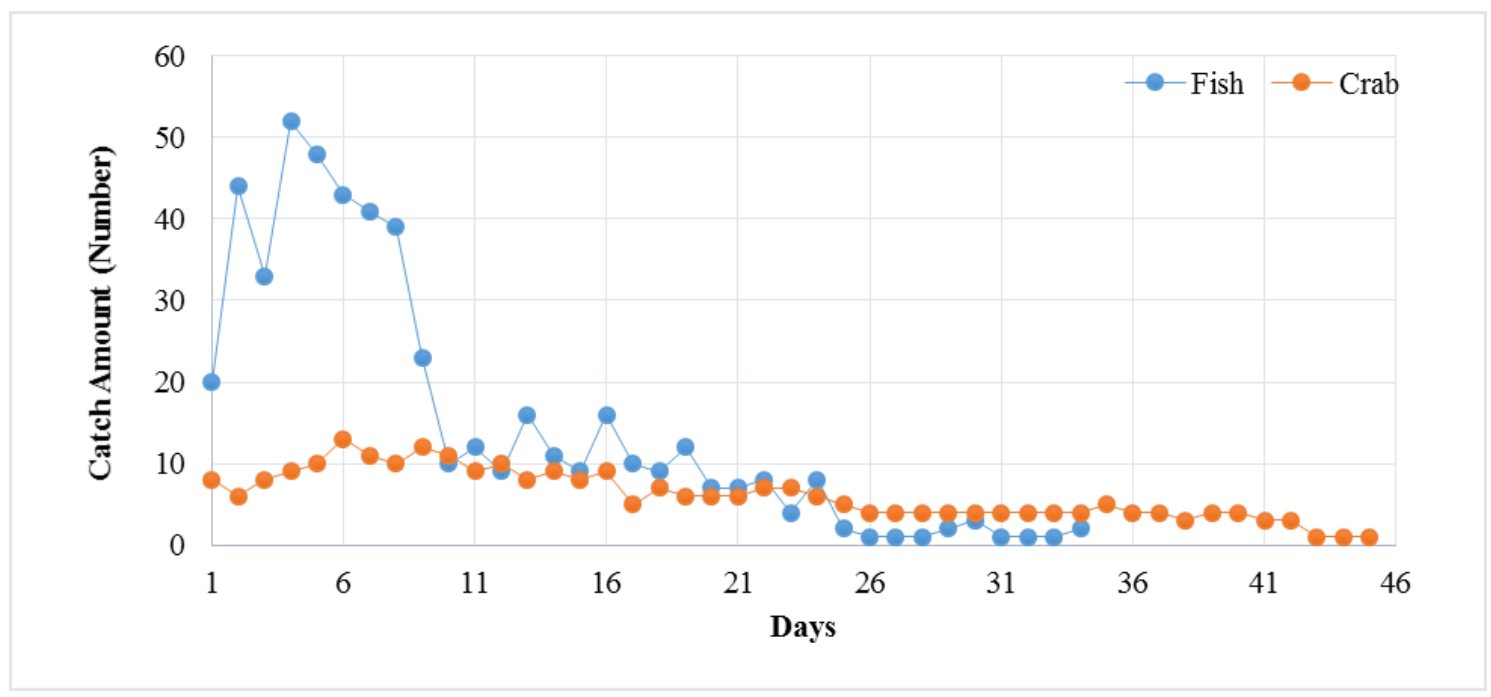

Figure 5. Change in total catch values in fish traps over time in trial 2. The amount of the fishing observed in fish traps by days in the second trail.

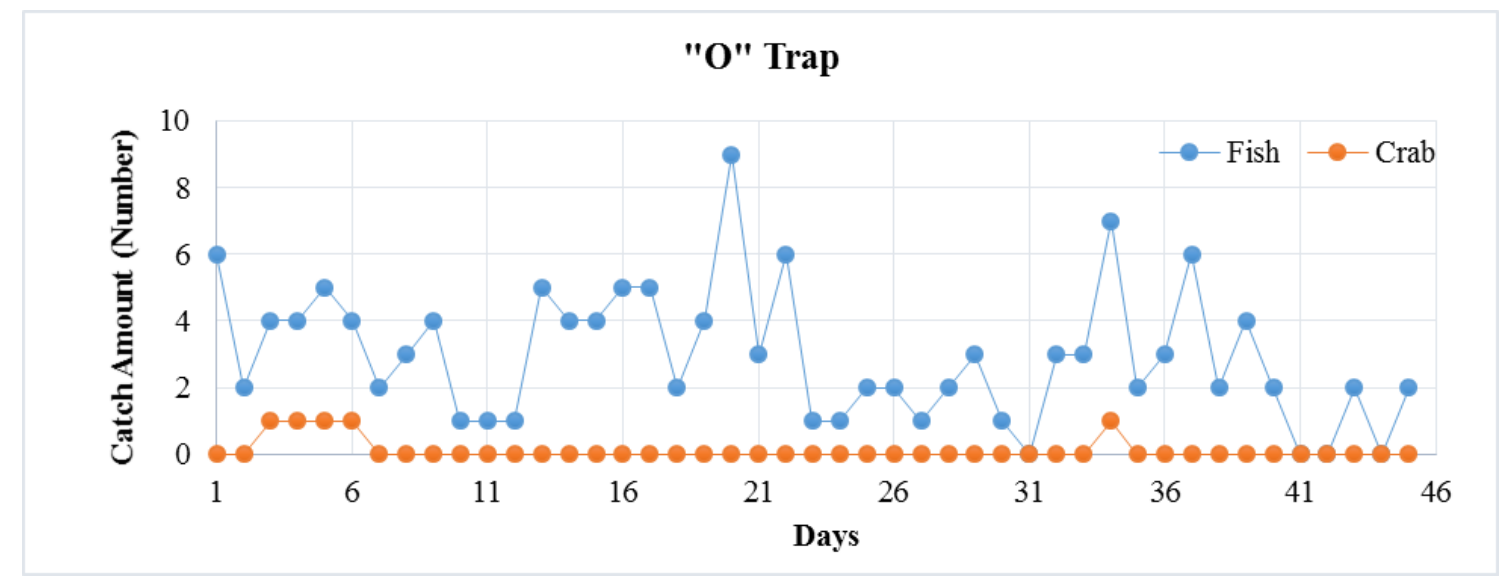

Figure 6. Changes in daily catches of "O" fish trap during the first trial. 


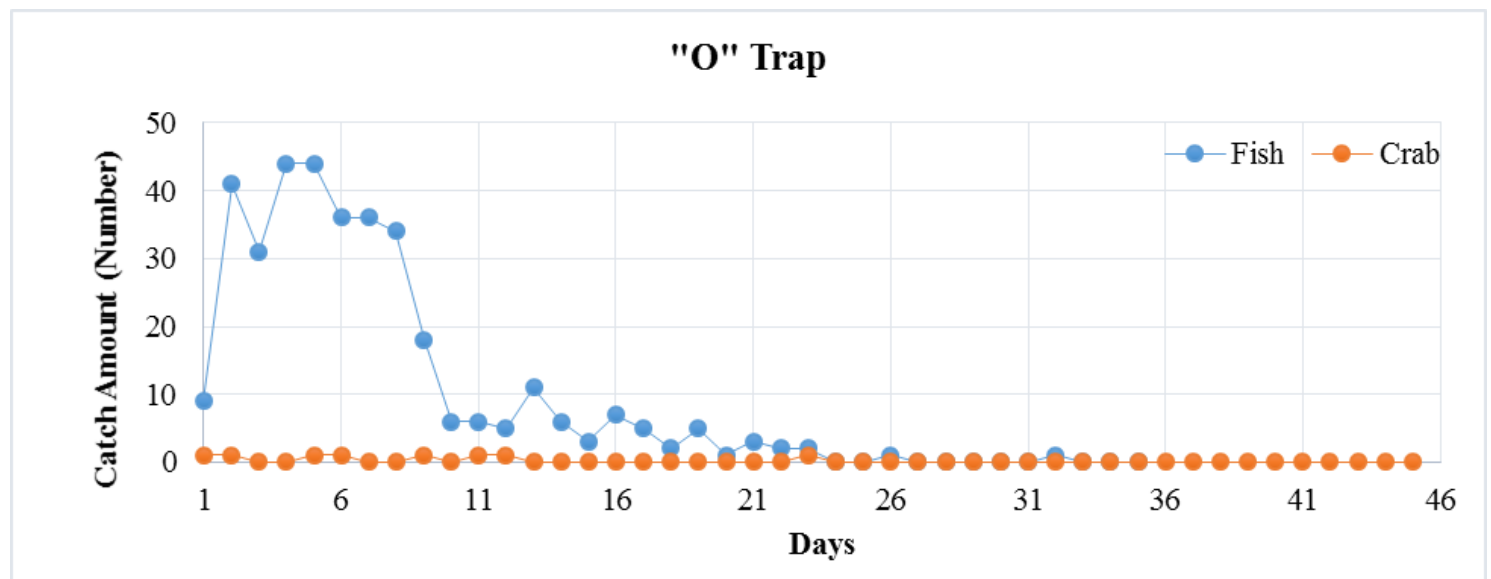

Figure 7. Changes in daily catches of "O" fish trap during the second trial.

In collapsible traps, cannibalism and ghost fishing were observed among crabs. 1, crab cannibalism started on day 18 th day and on day $20^{\text {th }}$, in the first and second trials, respectively. As a result the number of crabs in traps gradually decreased (Figure 8 and 9). Crab death was first observed on days $25^{\text {th }}$ and $42^{\text {nd }}$ in trial 1 and 2 , respectively. Following crab mortality, more crabs were observed in traps, due, possibly, to the smell of dead crabs. A few more crab deaths were observed shortly afterwards, and only the crabs that recently entered the traps survived by the end of the first trial. In the second trial, all crabs died after day $43^{\text {th }}$. Our observations indicated that mortality due to starvation occurred on day 22$24^{\text {th }}$ and on days $35-37^{\text {th }}$ in the first and second trials, respectively.

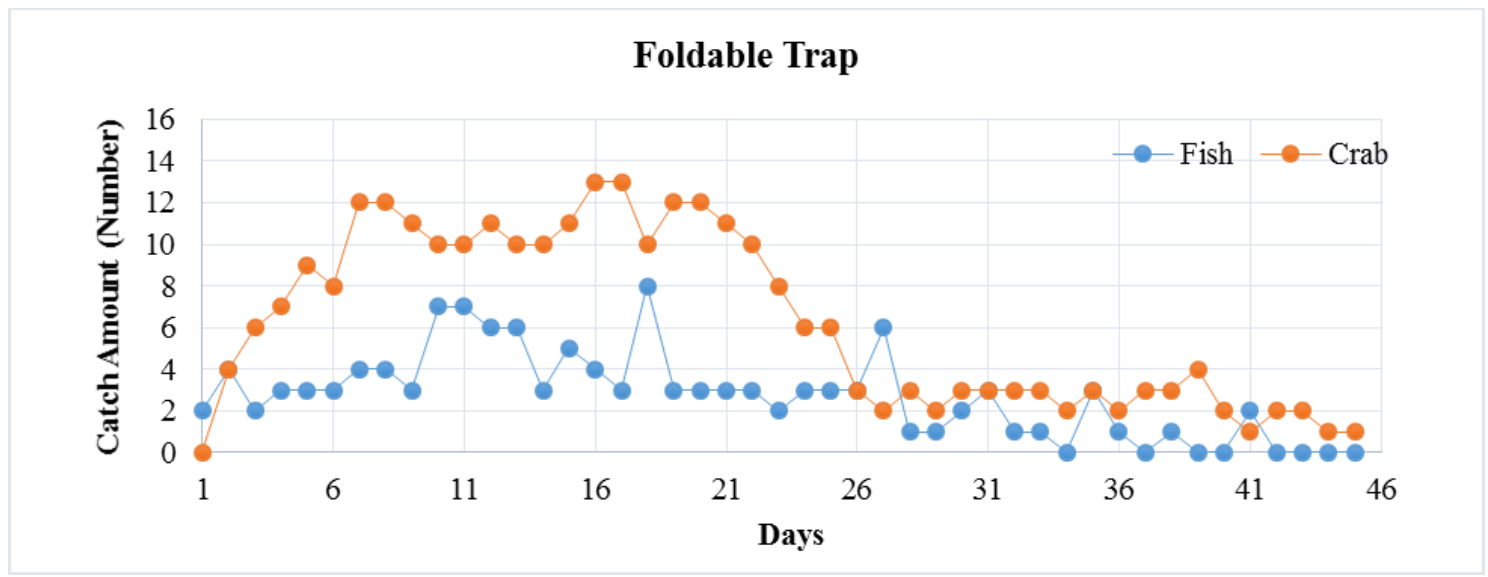

Figure 8. Changes in daily catches of foldable trap in trial 1.

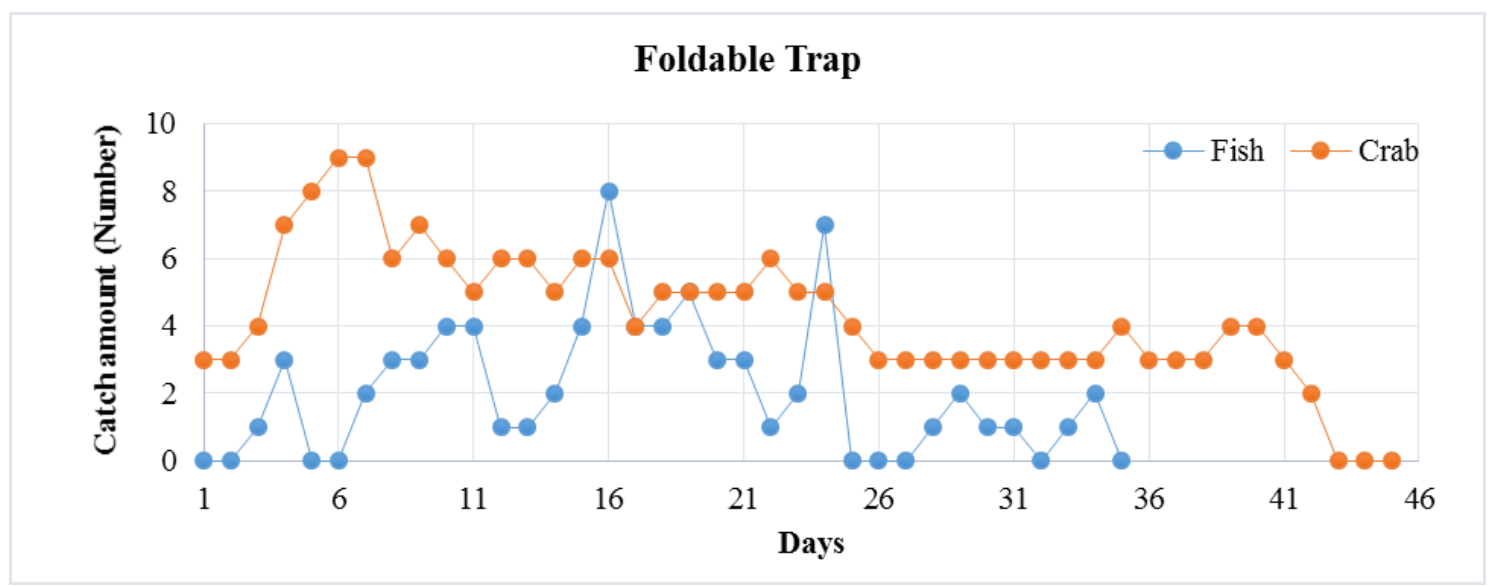

Figure 9. Changes in daily catches of foldable trap in trial 2. 
Cannibalism and ghost fishing were observed in crabs entering the baskets in the cylindrical traps with conical entrance. In the first trial, death from cannibalism was observed among crabs on the $16^{\text {th }}$ and $18^{\text {th }}$ days. On day $29^{\text {th }}$, death due to starvation was observed. In the second trial, crabs in traps were eaten by an octopus. Following day 17, no more crabs entered the trap. In the cylindrical traps, similar to the findings observed for the collapsible trap, crabs died of starvation 22 days after the beginning of first trial. being trapped in the fish traps (Figures 10 and $11)$.

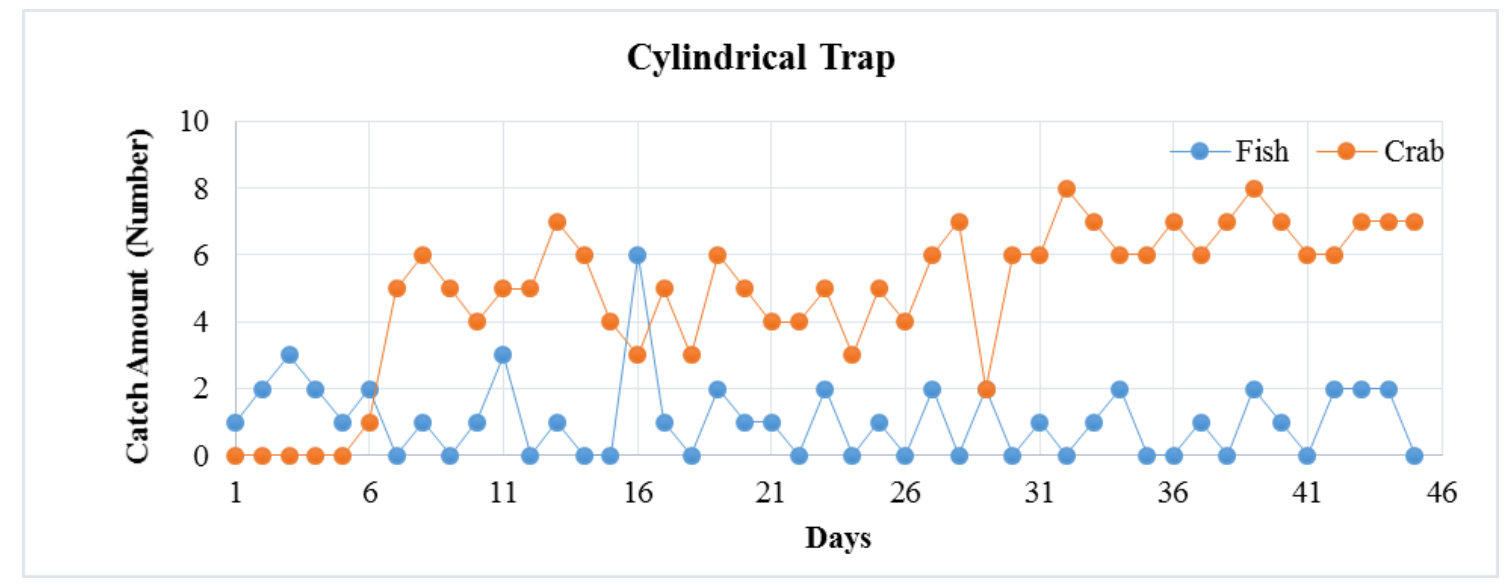

Figure 10. Changes in daily catches of cylindrical traps in trial 1.

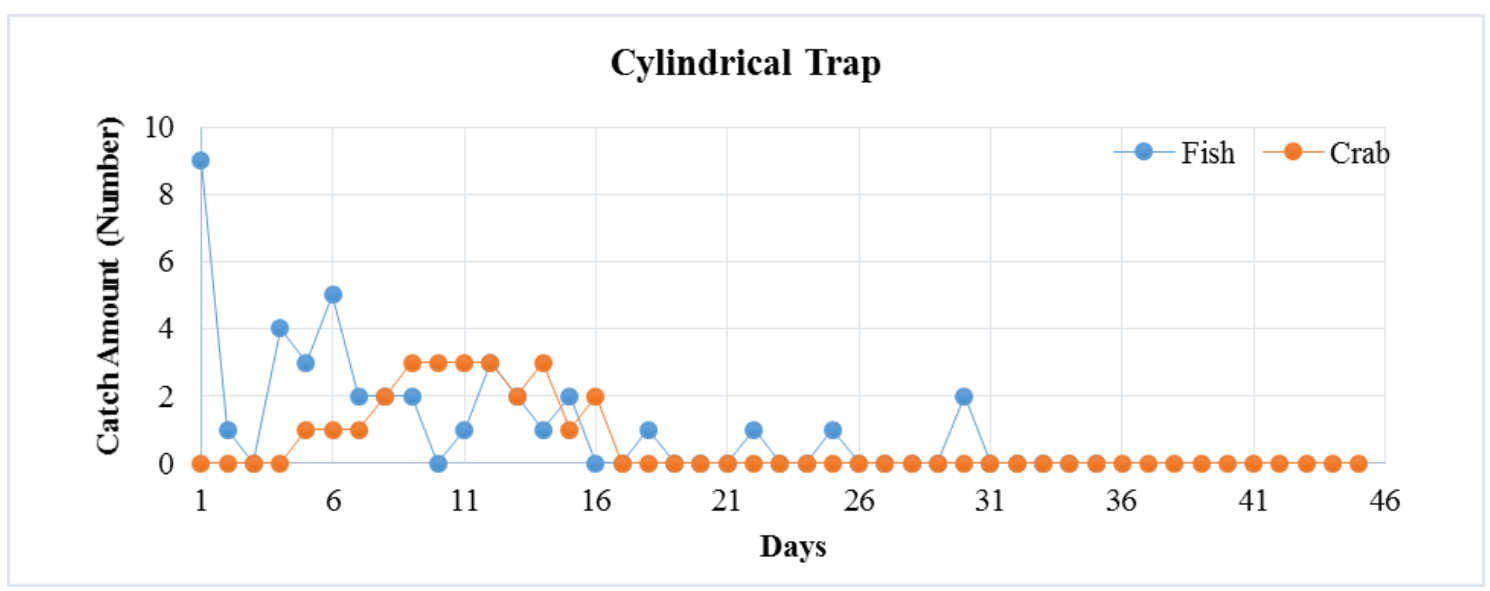

Figure 11. Changes in daily catches of cylindrical trap in trial 1.

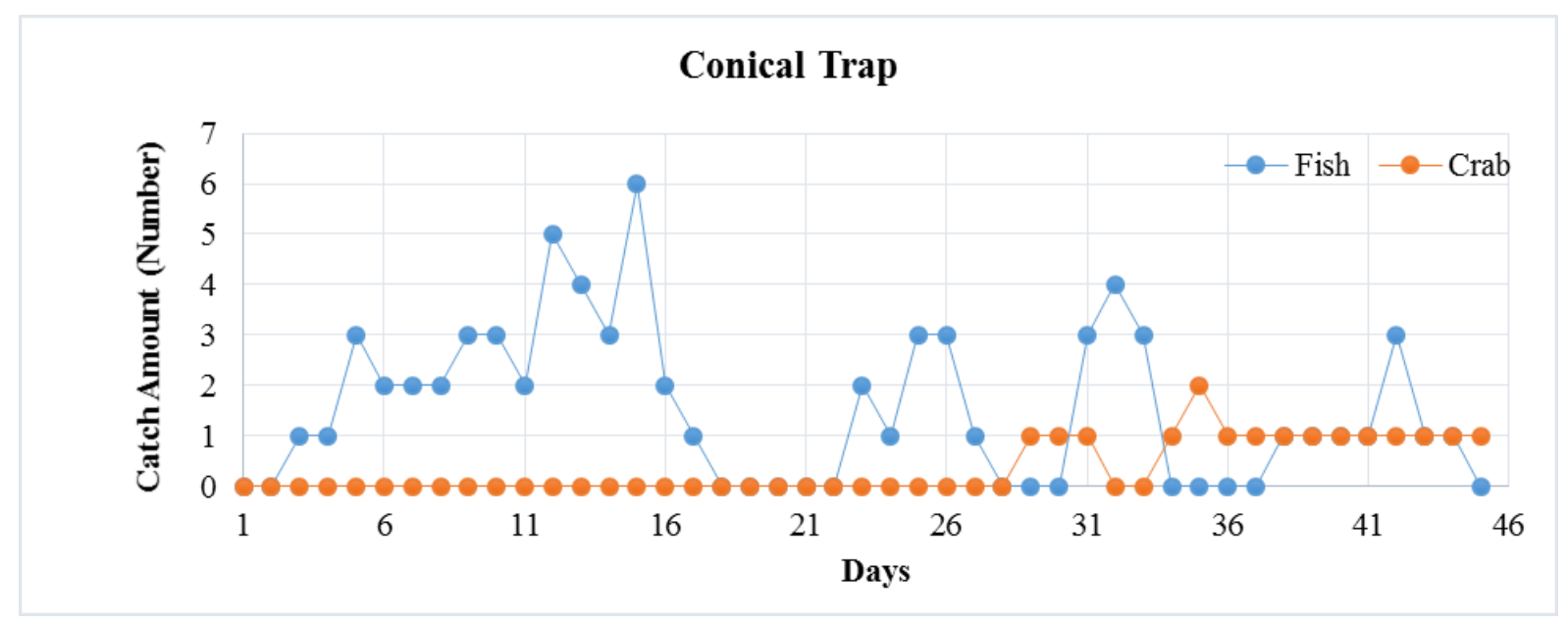

Figure 12. Changes in daily catches of conical trap in trial 1. 
Conical fish traps with a conical entrance from the top had the least amount of fish after the "O" trap. In the first trial, no deaths due to cannibalism or starvation were observed. In the second trial, cannibalism was not observed as there was only a single crab in the trap. However, crab mortality due to starvation was observed after 25 days of entrapment, when a single crab that entered the trap on day 13 died on day 38 in the second trial (Figures 12 and 13).
Visual observations indicated that, scorpionfish (Scorpaena porcus) with a retention time of 23 days (day 3 - day 26) had the maximum longevity among all species that were captured in trial 1 (Table 2). In the second trial, both the two-banded sea bream bream (Diplodus vulgaris) and the scorpion fish (Scorpaena porcus) had a retention time of 9 days (Table 3).

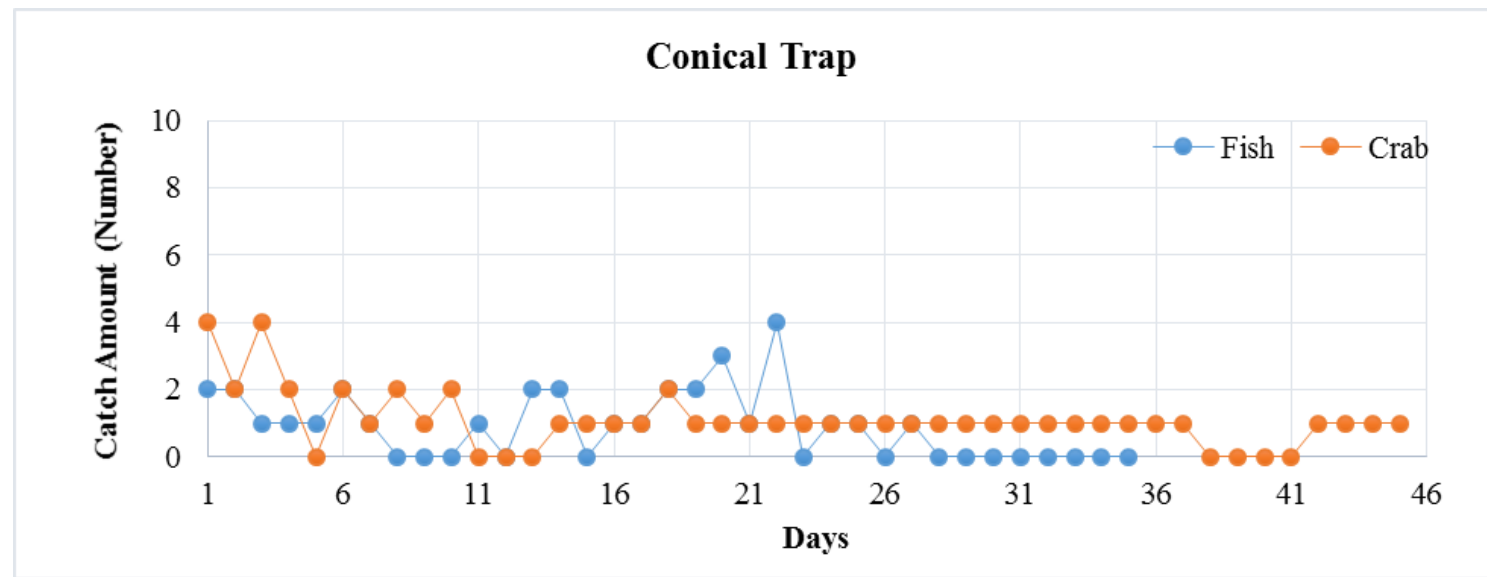

Figure 13. Changes in daily catches of conical trap in trial.

Table 2. Maximum retention times of species in traps in trial 1

\begin{tabular}{lcl}
\hline Species & $\begin{array}{c}\text { Maximum Retention Time in } \\
\text { Fish Traps (Day) }\end{array}$ & Fish Trap Model \\
\hline Symphodus tinca & 4 & "O" shape \\
Symphodus rostratus & 1 & "O" shape \& Foldable \\
Serranus cabrilla & 1 & All type \\
Serranus scriba & 1 & All type \\
Spondyliosoma cantharus & 1 & "O" shape \\
Diplodus annularis & 4 & "O" shape \& Cylindrical \\
Diplodus vulgaris & 6 & Conical \\
Diplodus sargus & 2 & "O" shape \\
Diplodus puntazzo & 1 & All type \\
Scorpaena porcus & 23 & Foldable \\
Conger conger & 8 & Foldable \\
Mullus surmuletus & $22-2 *^{\prime}$ & All type \\
Optopus vulgaris & 4 & Cylindrical \\
Sepia officinalis & 7 & "O" shape \\
Maja crispata & Cylindrical \& Foldable \\
\hline
\end{tabular}

* At the end of this time starvation death (Ghost fishing) was observed. 
Table 3. Maximum retention times of species in traps traps in trial 2.

\begin{tabular}{lcl}
\hline Species & $\begin{array}{c}\text { Maximum Retention Time in } \\
\text { Fish Traps (Day) }\end{array}$ & Fish Trap Model \\
\hline Symphodus tinca & 4 & "O" shape \\
Serranus scriba & 4 & "O" shape \\
Spondyliosoma cantharus & 1 & "O" shape \\
Diplodus annularis & 6 & "O" \& Conical \\
Diplodus vulgaris & 9 & "O" shape \\
Diplodus sargus & 8 & "O" shape \\
Sarpa salpa & 6 & "O" shape \\
Diplodus puntazzo & 7 & "O" shape \\
Scorpaena porcus & 9 & Foldable \\
Gobius sp. & 1 & Foldable \\
Conger conger & 5 & Conical \\
Mullus surmuletus & 4 & "O" shape \\
Optopus vulgaris & 1 & Foldable \\
Sepia officinalis & 2 & "O" shape \\
Maja crispata & $35-37 *$ & Foldable \\
\hline
\end{tabular}

* At the end of this time starvation death (Ghost fishing) was observed

It has been observed that the fish with higher swimming activity escaped from the traps sooner than others. In addition, a total of 6 mortalities were observed as a result of physical injuries during escape attempts in species such as the striped red mullet (Mullus surmuletus) and the annular sea bream (Diplodus annularis). Particularly in folding fish traps where ghost fishing was observed, 3 mortalities were observed. In the first trial, mortality of striped red mullet and annular sea bream occurred on day $10^{\text {th }}$ and $13^{\text {th }}$ days, respectively. In the second trial, striped red mullet mortality was observed on day $21^{\text {st }}$.

Visual observations indicated predation of entrapped fish by the European conger (Conger conger) in "O" traps on day 8 and 9 , in trial 2 . After predation by the conger, only a few fish entered the traps until the end of the trial.

\section{Discussion}

In the present study, ghost fishing of any fish species by traps was not observed. However, accidental entanglement of 6 fishes by the mesh material covering traps were detected. Mollusks such as octopus and cuttlefish and all fish species excluding the scorpion fish, were observed to escape from the traps within 5-6 days of entrapment. Similar to our findings, ghost fishing of fish by traps were not observed in earlier studies. Watanuki et al. (2000) stated that the cuttlefish escaped from fish traps within 2 days of entrapment. Renchen et al. (2012), using cameras attached to fish traps, observed that maximum retention time for some fish species was only 15 minutes. Ayaz et al. (2006b), depending on the density of fish entrapped in fish traps, reported that fish could escape from traps within 10 days. In trial 1, fish and mollusc species except the scorpion fish escaped from the fish traps sooner than those in trial 2. A density dependent escape pattern may explain difference in escape time. When higher number of fish were entrapped within traps retention time increased. In contrast, retention time decreased when only a smaller number of fish were entrapped within cages. In addition, species composition is also an important factor. Scorpion fish is a slow swimmer and prefers to rest most of the time which may explain their late escape from the traps.

Underwater observations indicated that the effect of bait in traps decreased after 7 days but lasted up to 15 days. Bullimore et al., (2001) reported that baits in fish traps lost their function after 28 days. Longer duration of baits on the coasts of Wales may be due to cooler water temperatures $\left(8-10{ }^{\circ} \mathrm{C}\right)$ in this region compared to that on the North Aegean coast.

In foldable fish traps, cannibalism among crabs started between 18 - 20 days whereas mortality due to starvation were observed later, i.e 22-37 days after trap setup. Earlier mortalities were reported in other studies. For example, Kimker (1994) reported that mortalities in fish traps started 14 days after setup. In the present study, mortality of two species due to accidental entanglement and their consequent consumption by crabs in the trap may have delayed mortality due to starvation. Our results are in accordance with those reported by Kimker (1994). 
Our findings indicated that the location and design of trap entrance are critical for ghost fishing by fish traps. Ghost fishing was not observed in "O" shaped fish traps. The entrance funnel in "O" shaped fish traps is ground level, and therefore allows the crabs (M. crispata) move in and out of the trap relatively easier. In other fish traps, the distance between the bottom of the trap and the entrance funnel prevented crab escape from the traps. In conical traps, since the entrance was at the top of the cage, crabs hardly found the way into the trap and therefore, only a small number of crabs were observed.

Our observations showed that ghost fishing occurred long after baits in traps deteriorated. Similar results were reported from other studies. For example, a large number of crabs (74-223 individuals/year) were caught after the bait in the trap was consumed (Campbell \& Sumpton, 2009). In order to prevent ghost fishing, escape spaces, larger mesh sizes and designs that blocks up trap entrance after a given amount of soak time (period that traps remain in the sea) have been suggested (Campbell \& Sumpton, 2009). Long et al. (2014), using acoustic tags, monitored behavior of 192 crabs and reported that only 20 crabs entered the lost fish traps. In a study carried out using crab traps with exhausted baits, it was reported that a total of 1077 crabs were caught by traps with a mortality rate of $46 \%$ and an escape rate of $39 \%$ after a period of 1 year (Antonelis et al., 2011).

In conclusion, ghost fishing of crabs was observed in all trap types except the "O" shaped traps with "V" entrance. Other trap types should include design characteristics that allow trap deterioration after a given amount of soak time reduce ghost fishing.

\section{Acknowledgments}

This study was financially supported by TÜBITTAK Project no: 112Y191. This research is a part of Talip İBIN's MSc Thesis. The authors thank Uğur Özekinci, Uğur Altınağaç, Alkan Öztekin, Ata Aksu,Osman Odabaşı and Umut Tuncer for their valuable help during the survey.

\section{Conflict of Interests}

The authors declares that there are no conflicts of interests.

\section{Author contribution}

Talip İbin: Daving observation, Data collection, Writig the manuscript. Adnan Ayaz: Study design, Diving observation, Data collection, Writing the manuscript.

\section{References}

Al-Masroori, H., Al-Oufi, H., McIlwain, J.L., McLean, E. 2004. Catches of lost fish traps (ghost fishing) from fishing grounds near Muscat, Sultanate of Oman. Fisheries Research, 69(3): 407-414

Antonelis, K., Huppert, D., Velasques, D., June, J. 2011. Dungeness crab mortality due to lost traps and a cost-benefit analysis of trap removal in Washington state waters of the Salish Sea. North American Journal of Fisheries Management, 31: 880-893.

Ayaz, A. 2003. Denizde kaybolan av araçlarının yaptığ 1 istenmeyen avcılık üzerine araștırmalar. Ege Üniversitesi Fen Bilimleri Enstitüsü, Doktara tezi, İzmir, $79 \mathrm{~s}$.

Ayaz A., Ünal V., Özekinci U. 2004. İzmir Körfezi'nde hayalet avcılığa neden olan kayıp uzatma ağ1 miktarının tespitine yönelik bir araştırma. Ege Journal of Fisheries and Aquatic Sciences, .21: 35-38.

Ayaz, A., Acarli, D., Altinagac, U., Ozekinci, U., Kara, A., Ozen, O. 2006a. Ghost fishing by monofilament and multifilament gillnets in Izmir Bay, Turkey. Fisheries Research, 79(3): 267271.

Ayaz, A., Özekinci, U., Altınağac, U., Özen, Ö. 2006b. Üstten girişli yuvarlak tel sepetlerin hayalet avcılık açısından incelenmesi, Ege Journal of Fisheries and Aquatic Sciences, 23 (1/3): 351-354.

Ayaz, A., Ünal, V., Acarli, D., Altınağaç, U. 2010. Fishing gear losses in the Gökova Special Environmental Protection Area (SEPA), eastern Mediterranean, Turkey. Journal of Applied Ichthyology, 26: 416-419. DOI: 10.1111/j.14390426.2009.01386.x

Breen, P.A. 1985. Ghost fishing by dungeness crab traps: A preliminary report. Canadian Manuscript Reports of Fisheries and Aquatic Sciences, No. $1848,51-55$

Breen, P.A. 1987. Mortality of dungeness crabs caused by lost traps in the Fraser River Estaury, British Columbia. North American Journal of Fisheries Management, 7: 429-435.

Bullimore, B.A., Newman, P.B., Kaiser, M.J., Gilbert, S.E., Lock, K.M. 2001. A study of catches in a fleet of "ghost-fishing" pots. Fishery Bulletin, 99(2): 247-253.

Campbell, M.J., Sumpton, W.D. 2009. Ghost fishing in the pot fishery for blue swimmer crabs Portunus pelagicus in Queensland, Australia. Fisheries Research, 95(2-3): 246-253. DOI:10.1016/j.fishres.2008.09.026 
Guillory, V. 1989. An evaluation of different escape vents in blue crab (Calinectes sapidus) traps. Proceedings of the Louisiana Academy of Sciences, 52: 29-34.

Guillory, V. 1993. Ghost fishing by blue crab traps. North American Journal of Fisheries Management, 13: 459-466.

Guillory, V., Hein, S. 1998. A review and evaluation of ecsape rings in the blue crab traps. Journal of Shellfish Research, 17(2): 551-559.

Guillory, V., Prejean, P., 1998. Effect of a Terrapin Excluder Device on Blue Crab, Callinectes sapidus, Trap Catches. Marine Fisheries Review, 60(1): 38-40.

Hebert, M., Miron, G., Moriyasu, M., Vienneau, R., DeGrace, P. 2001. Efficiency and ghost fishing of snow crab (Chionoecetes opilio) traps in the Gulf of St. Lawrence. Fisheries Research, 52(3): 143153. DOI: S0165-7836(00)00259-9

ICES. 2007. Report of study group on the development of fish pots for commercial fisheries and survey purposes (SGPOT). 21-22 April 2007, Dublin, Ireland. ICES CM 2007/FTC:02, 18 pp.

Kim, S., Park, S.-W., Lee, K. 2014a. Fishing performance of environmentaly friendly tubular pots made of biodegradable resin (PBS/PBAT) for catching the conger eel Conger myriaster. Fish Science, 80: 887-895. DOI: 10.1007/s12562014-0785-z

Kim, S., Park, S., Lee, K. 2014b. Fishing performance of an Octopus minor net pot made of biodegradable twines. Turkish Journal of Fisheries and Aquatic Sciences, 14: 21-30. DOI: 10.4194/1303-2712-v14-1-03

Kimker, A. 1994. Tanner crab survial in closed pots. Alaska Fishery Research Bulletin,1(2): 179-183.

Long, W.C., Cummiskey, P.A., Munk, J.E. 2014. Effects of ghost fishing on the population of red king crab (Paralithodes camtschaticus) in Women Bay, Kodiak Island. Alaska. Fishery Bulletin, 112: 101-111. DOI:10.7755/FB.112.2-3.1
Nulk, V.E. 1978. The effects of different escape vents on the selectivity of lobstar traps. Marine Fisheries Review, 40(5-6): 51-58.

Parrish, F.A., Kazama, T.K. 1992. Evaluation of ghost fishing in the Hawaiian lobster fishery. Fishery Bulletin, 90: 720-725.

Pecci, K.J., Cooper, R.A., Newell, C.D., Clifford, R.A., Smolowitz, R.J. 1978. Ghost fishing of vented and un-vented lobster, Homarus americanus, traps. Marine Fisheries Review, 40(56): 9-43.

Renchen, G.F., Pittman, S.J., Brandt, M.E. 2012. Investigated the behavioral responses of trapped fishes using underwater video surveillance. Journal of Fish Biology, 81: 1611-1625. DOI:10.1111/j.1095-8649.2012.03418.x

Scarsbrooke, J.R., McFarlane, G.A., Shaw, W. 1988. Effectiveness of experimental escape mechanisms in sablefish traps. North American Journal of Fisheries Management, 8: 158-161.

Shepherd, G.R., Moore, C.W., Seagraves, R.J. 2002. The effect of escape vents on the capture of black sea bass, Centropristis striata, in fish traps. Fisheries Research, 54: 195-207. DOI: 10.1016/S0165-7836(00)00305-2

Smolowitz, R.J. 1978a. Trap design and ghost fishing - discussion. Marine Fisheries Review, 40(5-6): 59-67.

Smolowitz, R.J. 1978b. Trap design and ghost fishing - overview. Marine Fisheries Review, 40(5-6): 28.

Stevens, B.G., Vining, I., Byersdorfer, S., Donaldson, W. 2000. Ghost fishing by Tanner crab (Chionoecetes bairdi) pots off Kodiak, Alaska: pot density and catch per trap as determined from sidescan sonar and pot recovery data. Fishery Bulletin, 98(2): 389-399.

Watanuki, N., Hirayama, I., Kawamura, G. 2000. Why do cuttlefish Sepia esculenta enter fish trap traps? Space occupation habit hypothesis. Fisheries Science, 66: 190-197. 